\title{
Patient with Metastatic Breast Cancer Achieves Stable Disease for 5 Years on Graviola and Xeloda after Progressing on Multiple Lines of Therapy
}

\author{
Damien Mikael Hansra, Orlando Silva, Ashwin Mehta, Eugene Ahn \\ Department of Hematology and Oncology, Sylvester Comprehensive Cancer Center at the University of Miami, \\ Miami, USA \\ Email: dmhansra@med.miami.edu
}

Received 8 March 2014; revised 6 April 2014; accepted 5 May 2014

Copyright (C) 2014 by authors and Scientific Research Publishing Inc.

This work is licensed under the Creative Commons Attribution International License (CC BY).

http://creativecommons.org/licenses/by/4.0/

(c) (i) Open Access

\begin{abstract}
Breast cancer (BC) is the most common malignancy in women and is second to lung cancer in terms of cancer mortality. Treatment of $B C$ remains a challenge as current therapies are limited by toxicity and drug resistance. Graviola (Annona muricata) is a tree that grows in the tropics of North and South America. Traditionally, the leaves and stems from the graviola tree have been used for a wide range of human diseases including cancer. In vitro and in vivo studies demonstrate anticancer activity in BC however clinical studies are lacking. We present the first case demonstrating clinical benefit without side effects using graviola in a patient with $\mathrm{BC}$ whose disease was refractory to multiple lines of chemotherapy including anthracyclines and taxanes.
\end{abstract}

\section{Keywords}

Breast Cancer, Graviola, Therapy

\section{Introduction}

Breast cancer (BC) is the most common malignancy in women and treatment of BC remains challenge as current therapies are limited secondary to toxicity and drug resistance. New integrative treatment strategies should be explored. Graviola (Annona muricata) is an Amazon fruit tree that grows in the tropics of North and South America and has been used for a wide range of human diseases including inflammatory conditions, rheumatism, neuralgia, diabetes, hypertension, insomnia, cystitis, parasitic infections, and cancer. Despite graviola being used

How to cite this paper: Hansra, D.M., Silva, O., Mehta, A. and Ahn, E. (2014) Patient with Metastatic Breast Cancer Achieves Stable Disease for 5 Years on Graviola and Xeloda after Progressing on Multiple Lines of Therapy. Advances in Breast Cancer Research, 3, 84-87. http://dx.doi.org/10.4236/abcr.2014.33012 
for centuries, research on its health benefits has been extremely limited. To date there are no published reports on outcomes using graviola in cancer patients.

\section{Methods}

A retrospective chart review of one patient diagnosed with BC from 1999-2012. Detailed clinical history was obtained including age at diagnosis, stage at diagnosis, therapy (chemotherapy, hormone, graviola) and response to therapy. Review of laboratory data was performed including liver function testing and tumor markers. Finally imaging with FDG PET CT was reviewed from diagnosis to end of study.

\section{Results}

A 66-year-old female diagnosed with estrogen and progesterone receptor positive human epidermal growth factor receptor negative pT2N1M0 stage IIb of the left breast cancer diagnosed in 1998 status post lumpectomy, adjuvant anthracycline \& taxane based chemotherapy followed by breast radiation completed in 1999. She subsequently presented with biopsy proven lung metastasis in 2002. She was started on hormonal therapy and progressed on Femara, Tamoxifen, and Faslodex. Chemotherapy with Navelbine was initiated from March 2005 until February 2006, Abraxane, Avastin, Gemcitabine (AAG) from Feburary 2006 to May 2007, Doxil from May 2007 to September 2007. Unfortunately the patient was found to have new liver metastases and she was started on Xeloda $2500 \mathrm{mg}$ PO daily (2 weeks on 1 week off) at that time. The patient also started using graviola 10 - 12 dry leaves boiled in water for 5 - 7 minutes, 8 oz. PO daily at that time. Tumor markers at time of initiation of graviola and Xeloda were CEA $12.5 \mathrm{ng} / \mathrm{ml}(0.0-3.4 \mathrm{ng} / \mathrm{mL})$, CA 15-3 1249.0 U/ml (0.0 - $25.0 \mathrm{U} / \mathrm{mL})$, CA 27-29 $1295 \mathrm{U} / \mathrm{ml}$ (<38 U/mL). Tumor markers in April 2008 were: CEA $5.9 \mathrm{ng} / \mathrm{ml}$, CA 15-3 68.6 U/ml, CA 27-29 $113 \mathrm{U} / \mathrm{ml}$. Patient moved to Alaska and continued her regimen, then returned in December 2011 and autonomously discontinued graviola at that time. Labs in March 2012 showed AST 75 U/L (15 - 46 U/L) ALT 84 U/L (9 - 52 U/L), CEA $4.3 \mathrm{ng} / \mathrm{ml}$, CA 15-3 $25.7 \mathrm{U} / \mathrm{ml}$, CA $27.2935 \mathrm{U} / \mathrm{ml}$. Also, PET-CT at that time demonstrated worsening left upper lung disease. Graviola was re-initiated at this point and labs in November 2012 showed AST 43 U/L, ALT 50 U/L, CEA 2.9, CA 27-29 32 U/ml, CA 15-3 20.7 U/ml. Re-imaging with PET/CT in November 2012 showed stable disease. So far, patient has had stable disease and experienced no side effects from therapy for over 5 years.

\section{Discussion}

Breast cancer (BC) is the most common malignancy in women and is second to lung cancer in terms of cancer mortality. An estimated 234,580 Americans will be diagnosed with BC and 40,030 will die of the disease in the United States in 2013 [1]. Treatment of BC remains a challenge as current therapies are limited secondary to toxicity and drug resistance and alternative treatment strategies should be explored. Furthermore the incidence of breast cancer has been steadily increasing over the past few decades [2] necessitating development of greater preventative strategies. It is well established that increased consumption of fruits and vegetables is associated with a reduced risk of most cancers [3]. The beneficial effect is partly due to the fact that fruits and vegetables contain antioxidants, fiber, and other potentially antineoplastic compounds. For this reason, natural products have been investigated as potential anticancer agents with the most attractive feature of these agents being limited side effect profiles as compared to conventional chemotherapeutic drugs. Specific bioactive compounds in foods, notably sulfur-containing gluconsinolates and green tea polyphenols are associated with reduced risk of BC risk [4] [5]. Graviola (Annonaceous muricata L.) is an Amazon fruit tree that grows in the tropics of North and South America and is also known as soursop and guanabana. Traditionally, the leaves and stems from the graviola tree have been used for a wide range of human diseases including inflammatory conditions, rheumatism, neuralgia, diabetes, hypertension, insomnia, cystitis, parasitic infections, and cancer [6] [7]. Graviola has been widely consumed by indigenous people for centuries however research on its health benefits are extremely limited. To date there are no published reports on outcomes using graviola in cancer patients. We present the first case demonstrating clinical benefit using graviola in a patient with BC. Arguably, the patient was taking single agent chemotherapy however the median progression free survival on single agent Xeloda in the metastatic setting is only a few months [8]. Also, the patient's liver function tests were elevated off graviola in the absence of other non-metastatic causes of hepatic injury and then normalized once graviola was resumed. This further sup- 
ports the notion that graviola stabilized our patient's disease. The exact mechanism of graviola in cancer cells is under investigation. Annonaceous acetogenins, the major bioactive components in graviola, are derivatives of long chain fatty acids that are selectively toxic to cancer cells, including multidrug resistant cancer cell lines [9]-[13] [14]. One study found that graviola inhibited tumorgenicity and metastasis in pancreatic cancer cells in vitro and in vivo by inhibiting multiple signaling pathways that regulate metabolism, cell cycle, survival, and metastatic properties in pancreatic cells [15]. Another study demonstrated that graviola induced growth inhibition of human breast cancer cells in vitro and in vivo through a mechanism involving the EGFR/ERK signaling pathway [16]. In terms of toxicity, graviola may cause movement disorders and myeloneuropathy with symptoms mimicking Parkinson's disease [17]. Our patient did not suffer any significant side effects. Further clinical research is required to determine the efficacy, effective dose, potential drug interactions and toxicity so this plant-derived extract could potentially gain approval for usage in breast cancer patients.

\section{References}

[1] American Cancer Society (2012) Cancer Facts and Figures 2012. Atlanta GACS.

[2] Siegel, R., Ward, E., Brawley, O. and Jemal, A. (2011) Cancer Statistics 2011: The Impact of Eliminating Socioeconomic and Racial Disparities on Premature Cancer Deaths. CA: A Cancer Journal for Clinicians, 61, 212-236. http://dx.doi.org/10.3322/caac.20121

[3] Chakraborty, S., Baine, M.J., Sasson, A.R. and Batra, S.K. (2011) Current Status of Molecular Markers for Early Detection of Sporadic Pancreatic Cancer. Biochimica et Biophysica Acta (BBA), 1815, 44-64

[4] Duffy, C. and Cyr, M. (2003) Phytoestrogens: Potential Benefits and Implications for Breast Cancer Survivors. Journal of Women's Health, 12, 617-631.

[5] Mukhtar, H. and Ahmad, N. (2000) Tea Polyphenols: Prevention of Cancer and Optimizing Health. The American Journal of Clinical Nutrition, 71, 1698-1702.

[6] Taylor, L. (2002) Technical Data Report for Graviola: Annona muricata. Sage Press, Inc., Herbal Secrets of the Rainforest second ed.

[7] Adewole, S.O. and Caxton-Martins, E.A. (2006) Morphological Changes and Hypoglycemic Effects of Annona muricata Linn. (Annonaceae) Leaf Aqueous Extract on Pancreatic B-Cells of Streptozotocin-Treated Diabetic Rats. African Journal of Biomedical Research, 9, 173-187.

[8] Bajetta, E., Procopio, G., Celio, L., et al. (2005) Safety and Efficacy of Two Different Doses of Capecitabine in the Treatment of Advanced Breast Cancer in the Treatment of Advanced Breast Cancer in Older Women. Journal of Clinical Oncology, 23, 2155-2161. http://dx.doi.org/10.1200/JCO.2005.02.167

[9] Oberlies, N.H., Jones, J.L., Corbett, T.H., Fotopoulos, S.S. and McLaughlin, J.L. (1995) Tumor Cell Growth Inhibition by Several Annonaceous Acetogenins in an in vitro Disk Diffusion Assay. Cancer Letters, 96, 55-62. http://dx.doi.org/10.1016/0304-3835(95)92759-7

[10] McLaughlin, J.L. (2008) Paw Paw and Cancer: Annonaceous Acetogenins from Discovery to Commercial Products. Journal of Natural Products, 71, 1311-1321. http://dx.doi.org/10.1021/np800191t

[11] Tormo, J.R., Royo, I., Gallardo, T., Zafra-Polo, M.C., Hernandez, P., Cortes, D. and Pelaez, F. (2003) In Vitro Antitumor Structure-Activity Relationships of Threo/Trans/Threo Mono-Tetrahydrofuranicacetogenins: Correlations with Their Inhibition of Mitochondrial Complex I. Oncology Research, 14, 147-154.

[12] Chang, F.R. and Wu, Y.C. (2001) Novel Cytotoxic Annonaceous Acetogenins from Annona muricata. Journal of Natural Products, 64, 925-931. http://dx.doi.org/10.1021/np010035s

[13] Liaw, C.C., Chang, F.R., Lin, C.Y., Chou, C.J., Chiu, H.F., Wu, M.J. and Wu, Y.C. (2002) New Cytotoxic Monotetrahydrofuran Annonaceous Acetogenins from Annona muricata. Journal of Natural Products, 65, 470-475. http://dx.doi.org/10.1021/np0105578

[14] Oberlies, H.N., Chang, C.J. and McLaughlin, J.L. (1997) Structure-Activity Relationships of Diverse Annonaceous Acetogenins against Multidrug Resistant Human Mammary Adenocarcinomas (MCF-7/Adr) Cells. Journal of Medicinal Chemistry, 40, 2102-2106. http://dx.doi.org/10.1021/jm9700169

[15] Torres, M.P., et al. (2012) Graviola: A Novel Promising Natural Derived Drug That Inhibits Tumorgenicity and Metastasis of Pancreatic Cancer Cells in Vitro and in Vivo through Altering Cell Metabolism. Cancer Letters, 323, 29-40. http://dx.doi.org/10.1016/j.canlet.2012.03.031

[16] Yumin, D., Hogan, S., Schmelz, E.M., Young, H.J., Canning, C. and Zhou, K. (2011) Selective Growth Inhibition of Human Breast Cancer Cells by Graviola Fruit Extract in Vitro and in Vivo Involving Downregulation of EGFR Expression. Nutrition and Cancer, 63, 795-801. http://dx.doi.org/10.1080/01635581.2011.563027 
[17] Lannuzel, A., Michel, P.P., Caparros-Lefebvre, D., Abaul, J., Hocquemiller, R. and Ruberg, M. (2002) Toxicity of Annonaceae for Dopaminergic Neurons: Potential Role in Atypical Parkinsonism in Guadeloupe. Movement Disorders, 17, 84-90. http://dx.doi.org/10.1002/mds.1246 
Scientific Research Publishing (SCIRP) is one of the largest Open Access journal publishers. It is currently publishing more than 200 open access, online, peer-reviewed journals covering a wide range of academic disciplines. SCIRP serves the worldwide academic communities and contributes to the progress and application of science with its publication.

Other selected journals from SCIRP are listed as below. Submit your manuscript to us via either submit@scirp.org or Online Submission Portal.
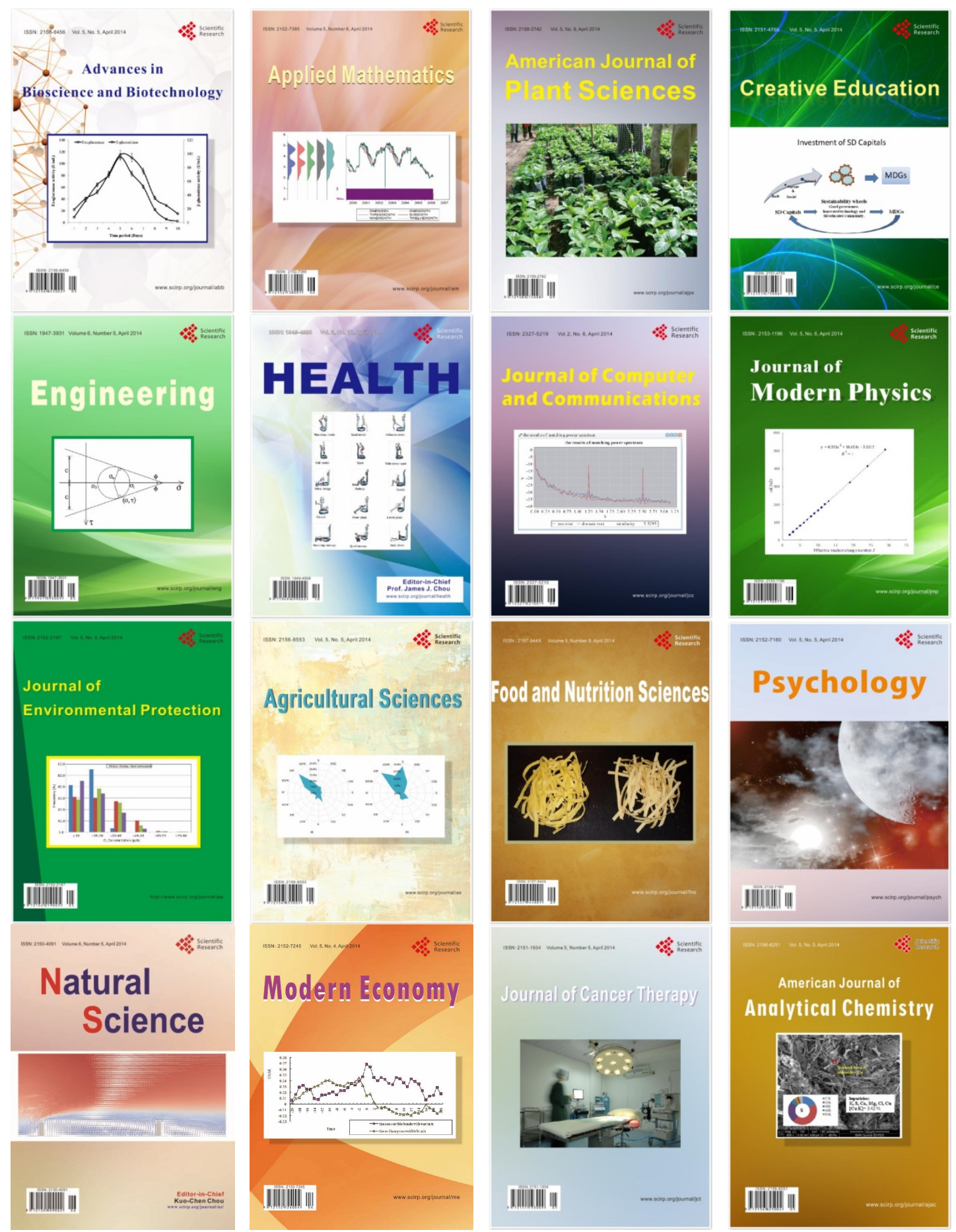